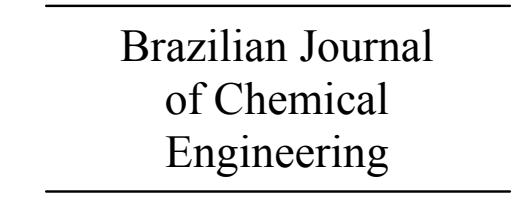

ISSN 0104-6632

Printed in Brazil

www.abeq.org.br/bjche

Vol. 31, No. 01, pp. 79 - 93, January - March, 2014

\title{
CLAY NANOPARTICLES EFFECTS ON PERFORMANCE AND MORPHOLOGY OF POLY(VINYLIDENE FLUORIDE) MEMBRANES
}

\author{
A. C. D. Morihama* and J. C. Mierzwa \\ Departamento de Engenharia Hidráulica e Ambiental, Escola Politécnica, Universidade de São Paulo, \\ Av. Prof. Almeida Prado 83, Trav. nº 2, CEP: 05508-900, São Paulo - SP, Brazil. \\ CIRRA, Centro Internacional de Referência em Reúso de Água, \\ Av. Prof. Lúcio Martins Rodrigues, 120, CEP: 05.598-000, "Phone: + (55) 11980830271 , \\ E-mail: anamorihama@usp.br
}

(Submitted: October 21, 2012 ; Revised: May 2, 2013 ; Accepted: May 15, 2013)

\begin{abstract}
In this study, a comparison between neat poly(vinylidene fluoride) (PVDF) membrane and composite (PVDF-Nanoclay and PVDF-PVP-Nanoclay) membranes is presented. All membranes were synthesized by the phase inversion process, using $18 \%$ PVDF, n-methylpyrrolidone as solvent and water as the non-solvent. Demineralized water cross-flow permeation tests were conducted to evaluate the membranes performance. Scanning electron microscopy (SEM) images of the membranes surface and cross-section and water contact angle measurements were used to estimate additives effects on membranes morphology. The results indicate that dopant addition affected membrane permeate flux and morphology. The $4 \%$ nanoclay composite membrane resulted in the highest ultrapure water permeability $\left(0.9130 \mathrm{~m}^{3} \cdot \mathrm{m}^{-2} \cdot \mathrm{h}^{-1} \cdot \mathrm{MPa}^{-1}\right)$, lower hydraulic resistance $\left(3.27 \times 10^{+12} \cdot \mathrm{m}^{-1}\right)$, lower contact angle $\left(87.1^{\circ}\right)$ and highest surface porosity $(0.95 \%)$. Furthermore, it was verified that the membrane surface porosity increased with increasing clay nanoparticles concentrations. It was observed that the morphology of the membranes with clay nanoparticle addition is characterized by a thin surface layer, with macro-pores, a thin bottom layer, which has a sponge-like structure with micro-pores and a thick intermediate layer, with finger-like pores and macro-pores. It was also verified that the introduction of PVP promotes a denser morphology compared with membranes without it. Based on the SEM surface and cross-sectional images and permeability tests, it became evident that the internal pore morphology plays an important role in membrane performance, because the higher the frequency and extent of the finger-like pores in the intermediate layer the higher is the membrane permeability. These preliminary results indicated that the use of nanoclay as an additive for membrane casting is a promising procedure for improving membrane performance for water and wastewater treatment.

Keywords: Ultrafiltration; Clay Nanoparticles; Poly(vinylidene fluoride); Water Treatment; Performance; Morphology.
\end{abstract}

\section{INTRODUCTION}

Poly(vinylidene fluorine) (PVDF) is a semi-crystalline polymer. The main macromolecular straight chain of PVDF is surrounded by fluorine and hydrogen atoms $\left(-\mathrm{CH}_{2}-\mathrm{CF}_{2}-\right)$. Its crystalline structure and spatial arrangement of $\mathrm{CH}_{2}$ and $\mathrm{CF}_{2}$ groups along the polymer chain result in excellent mechanical stability (Lui et al., 2011b). The high electronegativity of fluorine atoms and the high dissociation energy of the $\mathrm{C}-\mathrm{F}$ bond provide a better thermal stability compared with hydrocarbon polymers (Lovinger and Reed, 1980). Furthermore, PVDF is chemically stable to a wide range of chemical products such as halogens,

*To whom correspondence should be addressed 
oxidants, inorganic acids and aromatic, aliphatic and chlorinated solvents (Hashim et al., 2011). These PVDF properties associated with its low price, radiation resistance, low surface energy and dielectric constant have made it one of the most popular and usual polymers for microfiltration (MF) and ultrafiltration (UF) membranes (Lui et al., 2007; Zhao et al., 2008).

However, despite the previously presented advantages, PVDF has an intrinsic hydrophobicity. Thus, PVDF membranes have limitations for water, sewage and aqueous mixtures treatment (Lui et al., 2007; Zhao et al., 2008), which restricts the use of this kind of polymer.

The PVDF membrane hydrophobicity results in low membrane wettability and higher resistance for water flow, because there are no hydrogen bonding interactions in the boundary layer between the membrane interface and water. Moreover, hydrophobic membranes are more susceptible to fouling during treatment of aqueous solutions containing natural organic matter (NOM) (Lui et al., 2011b). As water molecules repulsion by hydrophobic surfaces is a spontaneous process with an increase in entropy, NOM molecules have a tendency to adsorb onto the membrane surface (Brant and Childress, 2004; Du et al., 2009).

In order to incorporate hydrophilic proprieties into conventional hydrophobic PVDF membranes for better performance, several membrane modification methods have been explored (Zhao et al., 2008). The blending modification method is ordinarily used to obtain the desired functional properties during membrane synthesis. In this way, the synthesis and modification processes can be performed in only one step (Zhao et al., 2008). Until now, three main types of additives have been used for PVDF membrane modification: hydrophilic polymers or pore-forming (polyvinylpyrrolidone - PVP and poly(methyl methacrylate) PMMA), amphiphilic copolymers (P(MMA-r-POEM) or P(MMA-r-PEGMA); PVDF-g-POEM; PVDF-gPMAA; PVDF-g-PEGMA; PVDF-g-PAAc; PVDFg-PAAc-b-PNIPAAM; PVDF-g-PTMASPMA and HPE-g-MPEG) and inorganic particles $\left(\mathrm{TiO}_{2} ; \mathrm{SiO}_{2}\right.$; $\mathrm{Al}_{2} \mathrm{O}_{3}$ and $\mathrm{ZrO}_{2}$ ) (Liu et al., 2011b).

According to the results summarized in Liu et al. (2011b), the introduction of additives improved the pure water flux, increased the water flux recovery and decreased the contact angle. In most cases, exception made for P(MMA-r-POEM), HPE-gMPEG and $\mathrm{TiO}_{2}$, an improvement in the rejection rate was also observed when using additives.

In the past years, the addition of inorganic nanoparticles to polymer solutions has become an attrac- tive method for polymeric membrane synthesis and has been extensively studied because of its simplicity (Yan et al., 2006). Research has focused on the preparation of composite or organic-inorganic hybrid membranes by the incorporation of inorganic nanoparticles. As explained previously, this blending modification is intended to improve porous membrane performance, reducing the hydrophobicity and increasing fouling resistance and permeability, which result from a better control of membrane surface properties and pore morphology (Yan et al., 2006; Lui et al., 2011b). This is possible because nanoparticles have unique properties (electronic, magnetic, optical, thermal and mechanical stability) and also due to their small size, high activity and high surface area (Yan et al., 2006).

Bottino et al. (2001, 2002) and Lin et al. (2003) have shown that PVDF- $\mathrm{SiO}_{2}$ membrane morphology and elasticity are influenced by the mass of inorganic material. According to Cao et al. (2006), $\mathrm{PVDF}-\mathrm{TiO}_{2}$ membrane permeability and hydrophilicity show better results than simple PVDF membranes and also decreased median pore size and surface roughness. Cao et al. (2006) also conclude that $\mathrm{TiO}_{2}$ nanoparticles had a strong effect on the PVDF molecule's crystallization.

Yan et al. (2006) have shown that the addition of $\mathrm{Al}_{2} \mathrm{O}_{3}$ nanoparticles did not affect pore size and numbers or the formation of crystals. The surface morphology was modified by increasing the surface roughness, but this did not affect the performance. According to the author, the contact angle decreased, as well as tensile strength, while rupture elongation improved.

According to Ma et al. (2012) and Monticelli et al. (2007), the addition of nanoclay to a polysulfone (PSf) membrane can increase water permeate flux. Monticelli et al. (2007) demonstrated that modified membranes had a higher contaminant rejection rate when compared to pure polysulfone membranes. Also according to the cited authors, the modified (PSf)-clay showed a lower contact angle; the clay increased membrane wettability at the same time that the mechanical properties were improved. On the other hand, Ma et al. (2012) showed that the nanoclay had little effect on the hydrophilicity of membranes and that it deteriorates to some extent the membrane mechanical properties. Ma et al. (2012) demonstrated that the addition of nanoclay to polysulfone membranes can increase the ratio of large pores in the skin layer and also the pure water flow. This may be due to a difference in the membrane composition. The aforementioned studies utilized different solvents, polymers and nanoclay concentra- 
tions. Furthermore, MA et al. (2012) also used a pore forming additive PEG 400.

Anadão et al. (2010) also studied the incorporation of nanoclay in PSf membranes. Although water permeation tests were not performed, their results showed that hydrophilicity, thermal stability and mechanical resistance of the composite membranes were improved.

Mierzwa et al. (2013) and Ghaemi et al. (2001) argued that clay nanoparticles increased polyethersulfone membrane permeability and induced changes in the membrane surface and morphology. Ghaemi et al. (2001) indicated that, at all nanoclay concentrations added, higher membrane hydrophilicity, porosity and a thinner skin layer were obtained. According to Mierzwa et al. (2013), nanoclay addition increased the contact angle, reduced the negative surface charge density and had no effect on membrane porosity and thickness. However, there was an optimum clay nanoparticle concentration above which membrane performance was significantly reduced.

Considering the promising results obtained in the cited studies, the main objective of this work is to evaluate the effect of inorganic clay nanoparticles (hydrophilic montmorillonite) on the morphology and performance of poly(vinylidene fluoride) (PVDF) ultrafiltration membranes synthesized by the phase inversion process, compared to the neat PVDF membrane.

\section{MATERIALS AND METHODS}

\section{Materials}

Studies were conducted with commercial poly (vinylidene fluoride) (PVDF) Kynar Flex ${ }^{\circledR} 2821$ (copolymer of poly(vinylidene fluorine) and hexafluoropropylene) kindly donated by Arkema Química Ltda.

N-methyl-2-pyrrolidone (NMP) with molecular weight of $99.1 \mathrm{~g} \mathrm{~mol}^{-1}$ was acquired from Labsynth produtos para laboratórios Ltda and was used as solvent.

The poly(vinylpyrrolidone) (PVP) with an average molecular weight of $10,000 \mathrm{~g} \mathrm{~mol}^{-1}$, from Sigma Aldrich, was used as pore former.

The clay nanoparticles (Montmorillinite - Nanomer ${ }^{\circledR}$ PGV), pellets approximately $1 \mathrm{~nm}$ thick and with an aspect ratio (length/width) ranging from 200-400 and molecular weight of $180.1 \mathrm{~g} \mathrm{~mol}^{-1}$, also from Sigma Aldrich, were used as additive.

All this chemicals were used as received. Demineralized water was prepared in the laboratory by double step reverse osmosis and used for membrane casting and membrane performance evaluation.

\section{Solution Preparation and Membrane Casting Procedure}

The reference solution was prepared with (PVDF) polymer at a fixed concentration (18\% by weight) dissolved in N-methyl-2-pyrrolidone (NMP) solvent, at $50{ }^{\circ} \mathrm{C}$ and stirred for 24 hours or until a homogenous polymeric solution was obtained using a mechanical stirrers (Fisaton 713D model).

For solutions with PVP, the final solution was obtained by the addition of $1 \%$ PVP (based on PVDF mass) together with PVDF. The PVP pore former addition was used to evaluate its combined effect on modified nanoclay membrane performance. For solutions containing clay nanoparticles $(2 \%$ and $4 \%$ based on PVDF mass) specific amounts of clay were added and dispersed in the previously prepared solutions. The range of clay nanoparticle concentration chosen was based on previous results obtained by Mierzwa et al. (2013) and Ghaemi et al. (2011). This solution was stirred for 24 hours at $50{ }^{\circ} \mathrm{C}$ for complete clay nanoparticle dispersion. Table 1 shows the composition of each solution prepared.

Table 1: Different composite PVDF membranes.

\begin{tabular}{|c|c|c|c|c|}
\hline Membrane & \begin{tabular}{|l|} 
PVDF \\
$(\mathbf{w t} \%)$
\end{tabular} & $\begin{array}{l}\text { NMP } \\
(w t \%)\end{array}$ & $\begin{array}{c}\text { PVP } \\
(w t \%)^{1}\end{array}$ & $\begin{array}{c}\text { Clay nanoparticles } \\
(\mathrm{wt} \%)^{1}\end{array}$ \\
\hline Control & 18 & 82 & 0 & 0 \\
\hline $0 \%$ PVP $+2 \%$ clay & 18 & 82 & 0 & 2 \\
\hline $0 \%$ PVP $+4 \%$ clay & 18 & 82 & 0 & 4 \\
\hline $1 \%$ PVP $+0 \%$ clay & 18 & 82 & 1 & 0 \\
\hline $1 \%$ PVP $+2 \%$ clay & 18 & 82 & 1 & 2 \\
\hline $1 \%$ PVP $+4 \%$ clay & 18 & 82 & 1 & 4 \\
\hline
\end{tabular}

${ }^{1} \mathrm{wt} \%$ is based on PVDF mass

Membranes were synthesized by the phase inversion process. Each final solution was spread onto a glass plate to produce a flat sheet membrane. The spreading itself was done using an automatic film applicator (ELCOMETER K4340 M10 model Automatic Film Applicator) coupled with bar coaters (ELCOMETER model 3700).

The polymeric film thickness adopted was $100 \mu \mathrm{m}$ with a casting velocity of $4 \mathrm{~cm} / \mathrm{s}$. The polymeric film was immediately immersed into the coagulation bath (demineralized water) at $25^{\circ} \mathrm{C}$, for 2 minutes or until the membrane was considered to be set. From the coagulation bath the cast membranes were transferred to another water bath (demineralized water at ambient temperature) for at least 24 hours to remove 
any residual solvent. Table 2 shows the casting process parameters.

Table 2: Casting parameters for flat sheet membranes.

\begin{tabular}{|l|l|}
\hline Casting Temperature & ambient \\
Casting knife & $100 \mu \mathrm{m}$ \\
Casting Speed & $0.04 \mathrm{~m} / \mathrm{s}$ \\
Coagulation Bath & demineralized water \\
Coagulation Bath Temperature & $25^{\circ} \mathrm{C}$ \\
Coagulation Bath Time & 2 minutes \\
\hline
\end{tabular}

\section{Membrane Performance Evaluation}

For performance evaluation, demineralized water flow tests were conducted using a cross flow test cell. Membranes used for these tests were removed from water and immersed in isopropyl alcohol for 24 hours; they were then dried naturally to prevent pore collapse (Porter, 1990). At least three different rectangular membrane samples $(0.13$ meters x 0.09 meters) were cut from different membranes. The system was pressurized at $0.3 \mathrm{MPa}$. Each test was run for one hour and permeate flow was obtained using a graduated cylinder and a stop watch. Measurements were recorded each five minutes.

Based on the series resistance model, the permeate flux $\left(\mathrm{J} ;\left[\mathrm{m}^{3} / \mathrm{m}^{2} . \mathrm{h}\right]\right)$ was calculated using Equation (1). The clean membrane hydraulic resistance $\left(R_{M}\right.$ $\left[\mathrm{m}^{-1}\right]$ ) was calculated using Equation (2).

$\mathrm{J}=\frac{\mathrm{V}}{\mathrm{A} \cdot \mathrm{t}}$

where $\mathrm{V}=$ permeate volume $\left(\mathrm{m}^{3}\right) ; \mathrm{A}=$ membrane effective surface area $\left(\mathrm{m}^{2}\right) ; \mathrm{t}=$ permeation time $(\mathrm{s})$

$$
\mathrm{R}_{\mathrm{M}}=\frac{\Delta \mathrm{P}}{\mu \times \mathrm{J}}
$$

where $\mathrm{J}=$ flux $\left(\mathrm{m}^{3} / \mathrm{m}^{2} . \mathrm{s}\right) ; \Delta \mathrm{P}=$ transmembrane pressure $(\mathrm{Pa}) ; \mu=$ dynamic water viscosity (Pa.s)

\section{Membrane Hydrophilicity}

The membrane hydrophilicity was estimated by measuring the water contact angle $\left(\theta ;\left[^{\circ}\right]\right)$ of a sessile drop. Contact angle measurements were carried out according to the ISO-15989 standard method (International Standard, 2004).

The membranes used for these tests were removed from water and immersed in isopropyl alcohol for 24 hours and then dried naturally to prevent pore collapse. Two different rectangular membrane samples were cut from different mem- branes. At least fifteen tests for each type of membrane were made. Results were analyzed by the Median Test and Mann-Whitney Test.

\section{Membrane Morphology Evaluation}

Based on the Scanning Electron Microscopy (SEM) images, it was possible to determine the membrane pore sizes and distribution, using the ImageJ software. Membrane surface and cross-sectional images were obtained using a Quanta 600FEG Environmental Scanning Electron Microscope (ESEM), operated in the secondary electrons detection mode with a $10 \mathrm{kV}$ accelerating voltage. All membrane samples were coated with a platinum layer.

\section{RESULTS AND DISCUSSION}

\section{Membrane Performance Evaluation}

Demineralized water flow tests were performed as a preliminary procedure to investigate the effect of clay nanoparticles and PVP addition on the PVDF membranes performance.

From Table 3 and Figure 1 it is possible to verify that the use of additives affects membrane permeability. The highest permeate flux $\left(0.9130 \mathrm{~m}^{3} \cdot \mathrm{m}^{-2} \cdot \mathrm{h}^{-1} \cdot \mathrm{MPa}^{-1}\right)$ was obtained for membranes cast with 0\% PVP and $4 \%$ clay, showing an increase of $732 \%$ compared with the control membrane. The second highest $\left(0.7473 \mathrm{~m}^{3} \cdot \mathrm{m}^{-2} \cdot \mathrm{h}^{-1} \mathrm{MPa}^{-1}\right)$ was obtained for membranes cast with $0 \%$ PVP and $2 \%$ clay, with is $581 \%$ higher than the control membrane. However, the variance test, for a 5\% significance level, between these two permeate flows, did not demonstrate that the variances are different. These results were expected because an improvement of pure water flux upon clay nanoparticle addition was also observed in previous studies (Mierzwa et al., 2013; Ma et al., 2012, Ghaemi et al., 2011; Monticelli et al., 2007).

The PVP addition also improved the pure water permeate flux. Comparing the (1\% PVP $+0 \%$ clay) membrane permeability with the control membrane permeability the improvement was around 230\%. This result agrees with previous reports that discuss the PVP influence on membrane morphology. According to Liu et al. (2011b), PVP acts more like a pore former in the modification of the PVDF membrane than as a hydrophilic additive because it is water soluble and can be removed during membrane preparation and operation. Furthermore, PVP addition affects the thermodynamics and kinetics of the casting process, changing membrane morphology, pore size and pore size distribution. 
Table 3: Effect of additives on PVDF membrane performance.

\begin{tabular}{|c|c|c|c|c|}
\hline \multirow{2}{*}{ Membrane } & \multirow{2}{*}{$\begin{array}{l}\text { Average permeate flow } \\
\qquad\left(\mathrm{m}^{3} \cdot \mathrm{m}^{-2} \cdot \mathrm{h}^{-1}\right)\end{array}$} & \multicolumn{2}{|c|}{ Average permeability } & \multirow{2}{*}{$\begin{array}{l}\text { Median hydraulic resistance } \\
\qquad\left(10^{+12} \mathrm{~m}^{-1}\right)\end{array}$} \\
\hline & & $\left(\mathrm{m}^{3} \cdot \mathrm{m}^{-2} \cdot \mathrm{h}^{-1} \cdot \mathrm{MPa}^{-1}\right)$ & $\left(L \cdot m^{-2} h^{-1} \cdot\right.$ bar $\left.^{-1}\right)$ & \\
\hline Control & 0.032 & 0.1098 & 10.98 & 21.75 \\
\hline $0 \% \mathrm{PVP}+2 \%$ clay & 0.224 & 0.7473 & 74.73 & 3.47 \\
\hline $0 \% \mathrm{PVP}+4 \%$ clay & 0.274 & 0.9130 & 91.30 & 3.27 \\
\hline $1 \% \mathrm{PVP}+0 \%$ clay & 0.109 & 0.3623 & 36.23 & 7.94 \\
\hline $1 \%$ PVP $+2 \%$ clay & 0.180 & 0.6007 & 60.07 & 6.29 \\
\hline $1 \% \mathrm{PVP}+4 \%$ clay & 0.165 & 0.5494 & 54.94 & 8.25 \\
\hline
\end{tabular}
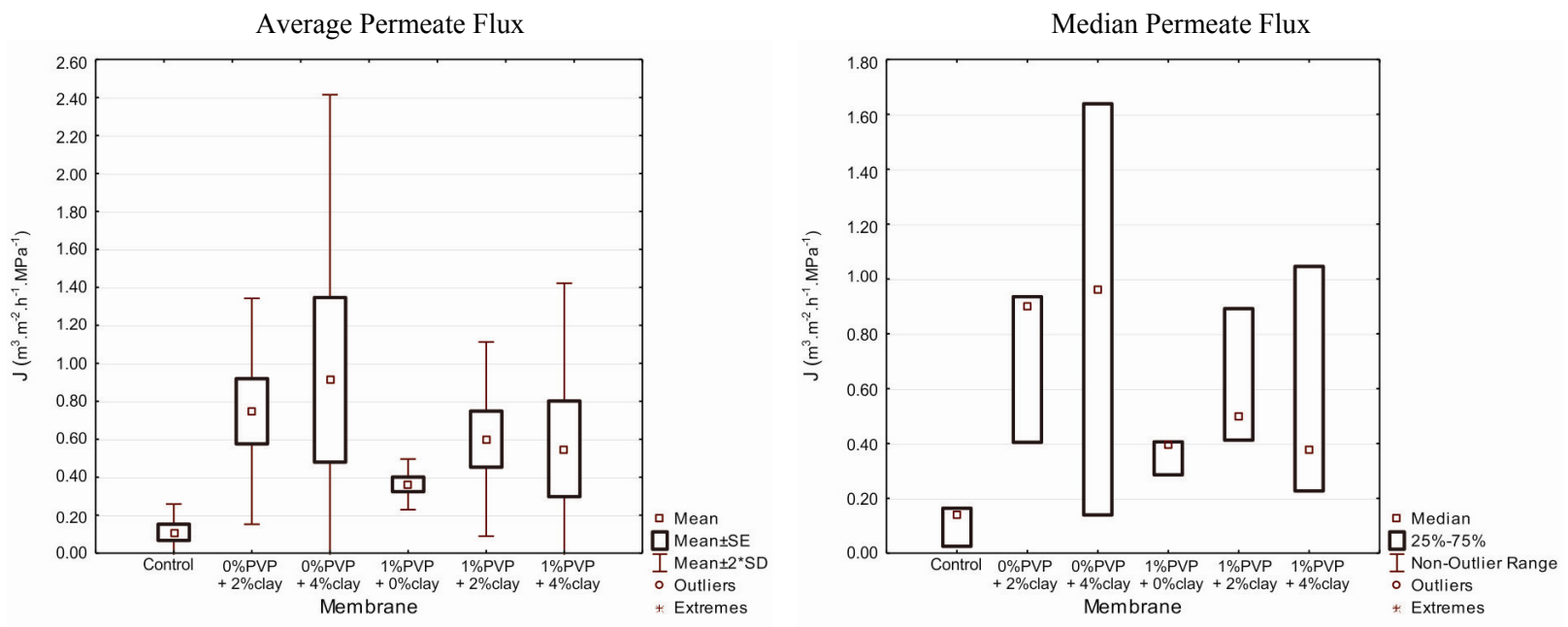

Figure 1: Additive effect on PVDF membrane permeability.

According to the results presented in Table 3 and Figure 1, the combination of clay nanoparticles and PVP can improved the pure water permeate flux around $447 \%$ and $400 \%$, respectively, for (1\% PVP $+2 \%$ clay) and ( $1 \%$ PVP $+4 \%$ clay) membranes, compared to the control membrane. Nevertheless, membranes made with the combination of clay nanoparticles and PVP presented lower permeability compared with the membranes in which only clay nanoparticles were used. This behavior is related to the small PVP average molecular weight $(10,000$ g.mol ${ }^{-1}$ ), which can lead to membranes with tight pores and reduced permeability. In order to confirm this hypothesis it is necessary to analyze and compare the membrane internal structure and also its separation capacity.

Table 3 also presents the results for membrane hydraulic resistance. The introduction of additives resulted in a lower hydraulic resistance. The hydraulic resistances for ( $0 \%$ PVP $+2 \%$ clay) and ( $0 \%$ PVP $+4 \%$ clay) membranes were about 6 to 7 times lower, respectively, when compared with control membrane. The other membranes had their hydraulic resistance reduced 3-fold relative to the control membrane. The variance test between the hydraulic resistances of ( $0 \%$ PVP $+2 \%$ clay) and ( $0 \%$ PVP + $4 \%$ clay) membranes indicated that they were not different at the $5 \%$ significance level.

The median hydraulic resistance results agrees with the water permeate flux results; membranes that had the highest flux showed lower hydraulic resistance.

\section{Membrane Hydrophilicity}

Results for the contact angle measurements are presented in Table 4 and Figure 2. Because the contact angle measurements were very similar, the Median Test and Mann-Whitney Test were performed to better understand these results. Table 5 and Table 6 present the test results.

Table 5 shows that, in most cases (except for pairs control $/ 0 \%$ PVP $+4 \%$ clay; $0 \%$ PVP $+2 \%$ clay $/ 1 \%$ PVP $+0 \%$ clay; $0 \%$ PVP $+2 \%$ clay $/ 1 \%$ PVP + $4 \%$ clay and $1 \%$ PVP $+0 \%$ clay $/ 1 \%$ PVP $+4 \%$ clay) the contact angle results do not have the same median at the $95 \%$ confidence level. Table 6 indicates that the contact angle measurements do not come from populations with the same average at the $95 \%$ confidence level. 
Table 4: Results of membrane hydrophilicity.

\begin{tabular}{|c|c|c|}
\hline Membrane & $\begin{array}{c}\text { Average } \\
\text { Contact Angle } \\
\left({ }^{\circ}\right) \\
\end{array}$ & $\begin{array}{c}\text { Median } \\
\text { Contact Angle } \\
\left({ }^{\circ}\right) \\
\end{array}$ \\
\hline Control & 86.6 & 87.0 \\
\hline $0 \%$ PVP $+2 \%$ clay & 98.9 & 98.5 \\
\hline $0 \% \mathrm{PVP}+4 \%$ clay & 88.1 & 87.1 \\
\hline $1 \%$ PVP $+0 \%$ clay & 100.2 & 99.7 \\
\hline $1 \%$ PVP $+2 \%$ clay & 92.2 & 92.8 \\
\hline $1 \% \mathrm{PVP}+4 \%$ clay & 99.0 & 97.2 \\
\hline
\end{tabular}

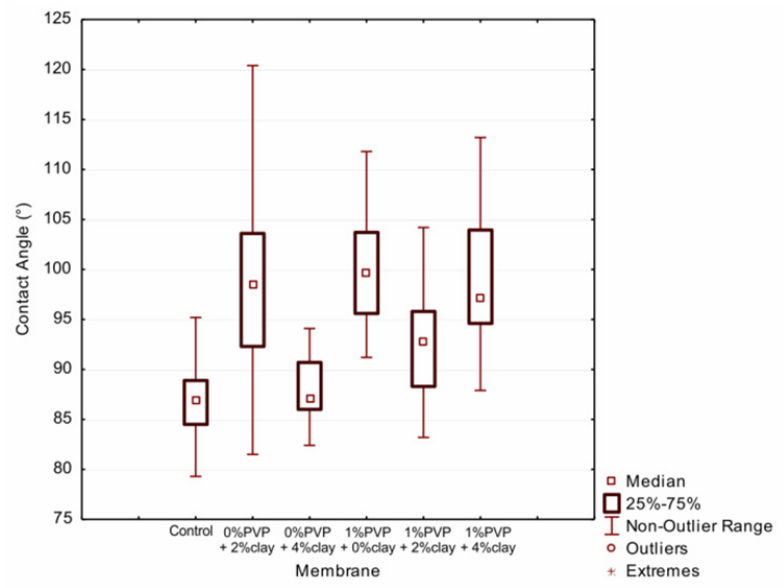

Figure 2: Median contact angles.

Table 5: Results of Median Test.

\begin{tabular}{|l|l|l|l|l|l|}
\hline & $\mathbf{0 \%}$ PVP + 2\% clay & $\mathbf{0 \%}$ PVP + 4\% clay & $\mathbf{1 \%}$ PVP + 0\% clay & $\mathbf{1 \%}$ PVP + 2\% clay & $\mathbf{1 \%}$ PVP + 4\% clay \\
\hline Control & Non Homogeneous & Homogeneous & Non Homogeneous & Non Homogeneous & Non Homogeneous \\
$0 \%$ PVP $+2 \%$ clay & & Non Homogeneous & Homogeneous & Non Homogeneous & Homogeneous \\
$0 \%$ PVP $+4 \%$ clay & & & Non Homogeneous & Non Homogeneous & Non Homogeneous \\
$1 \%$ PVP $+0 \%$ clay & & & Non Homogeneous & Homogeneous \\
$1 \%$ PVP $+2 \%$ clay & & & & Non Homogeneous \\
\hline
\end{tabular}

Table 6: Results of Mann-Whitney Test.

\begin{tabular}{|l|c|c|c|c|c|}
\hline & $\mathbf{0 \%}$ PVP + 2\% clay & $\mathbf{0 \%}$ PVP + 4\% clay & $\mathbf{1 \%}$ PVP + 0\% clay & $\mathbf{1 \%}$ PVP + 2\% clay & $\mathbf{1 \%}$ PVP + 4\% clay \\
\hline Control & Non Homogeneous & Non Homogeneous & Non Homogeneous & Non Homogeneous & Non Homogeneous \\
$0 \%$ PVP $+2 \%$ clay & & Non Homogeneous & Non Homogeneous & Non Homogeneous & Non Homogeneous \\
$0 \%$ PVP $+4 \%$ clay & & & Non Homogeneous & Non Homogeneous & Non Homogeneous \\
$1 \%$ PVP $+0 \%$ clay & & & & Non Homogeneous & Non Homogeneous \\
$1 \%$ PVP $+2 \%$ clay & & & & Non Homogeneous \\
\hline
\end{tabular}

The contact angle results showed that clay nanoparticles and PVP addition affected membrane hydrophilicity. According to previous studies (Ghaemi et al., 2011; Anadão et al., 2010; Monticelli et al., 2007), it was expected that additives would decrease the contact angle and increase hydrophilicity, but the results have shown the opposite, since the control membrane had the lowest contact angle. Mierzwa et al. (2013) and Ma et al. (2012) demonstrated that the nanoclay had little effect on the hydrophilicity of membranes.

Khulbe et al. (2003) concluded that the contact angle is related to the membrane surface roughness. The smaller membrane surface roughness, the smaller the contact angle. Therefore, the change in membrane contact angle using additives can be better explained by the changes in membrane roughness, as was pointed out by Mierzwa et al. (2013). 
The permeability results and median contact angle results show that although additive introduction did not improve membrane hydrophilicity, it improved membrane permeability for pure water. These results are counter intuitive since higher permeability is associated with a more hydrophilic membrane. According to Mierzwa et al. (2012), contact angle is not a good indicator to predict permeability. Moreover, their studies suggest that membrane structure and pore size analysis provide better insights to understand the effects of additives on membrane performance.

\section{Membrane Surface Morphology Evaluation}

Membrane surface morphology can be analyzed in terms of pore size, pore distribution and porosity. These characteristics can be evaluated by surface SEM image analysis, as presented in Figure 3.

In order to understand the effect of additives on membrane morphological characteristics, the surface pore distributions and surface porosity were determined with SEM image analysis using the ImageJ software, as show in Figure 4. The surface pore size distributions are shown in Figure 5.

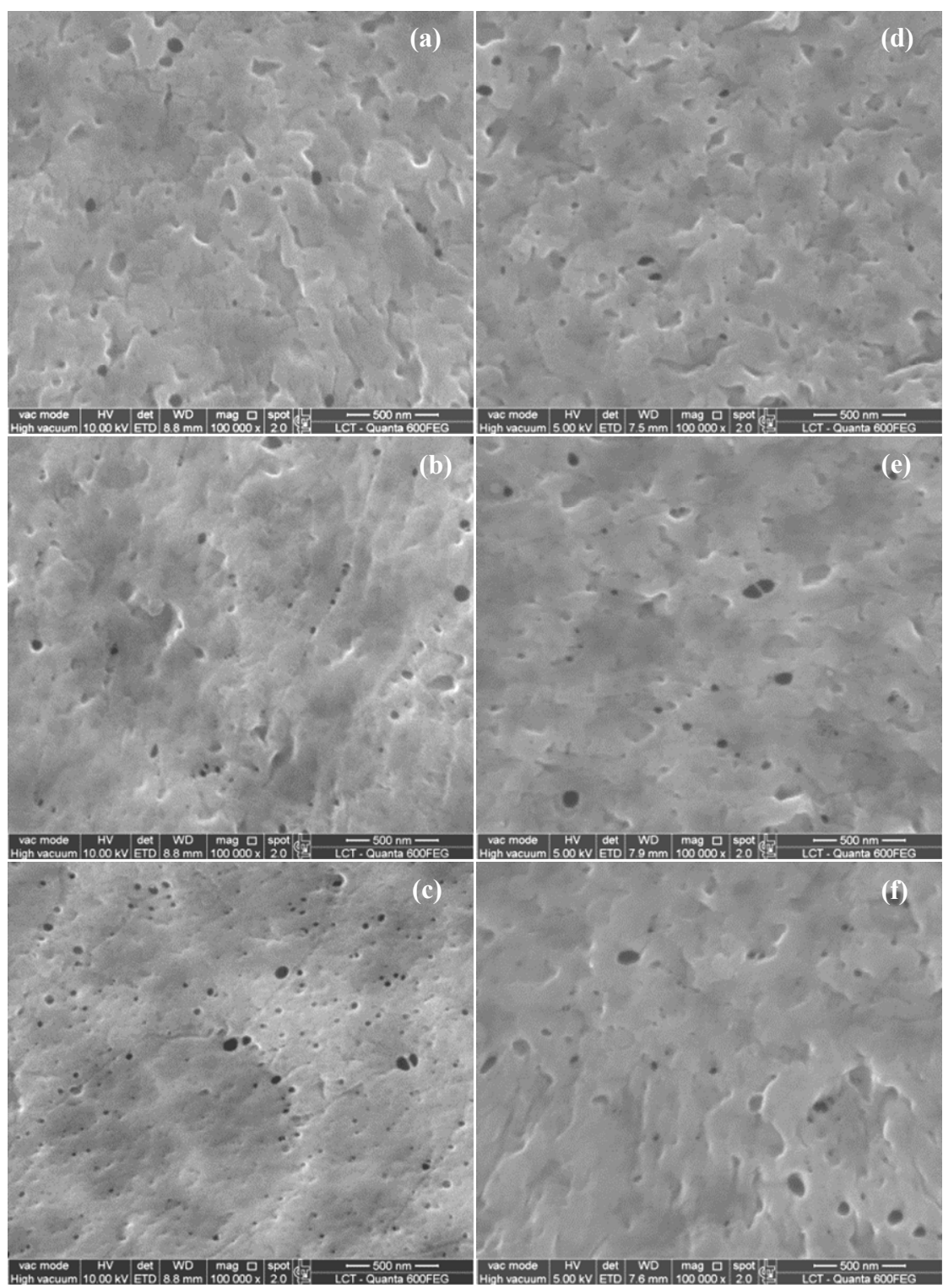

Figure 3: Membrane SEM surface images: (a) Control; (b) 0\% PVP + 2\% clay; (c) $0 \%$ PVP $+4 \%$ clay; (d) $1 \%$ PVP $+0 \%$ clay; (e) $1 \%$ PVP $+2 \%$ clay; (f) $1 \%$ PVP $+4 \%$ clay. 

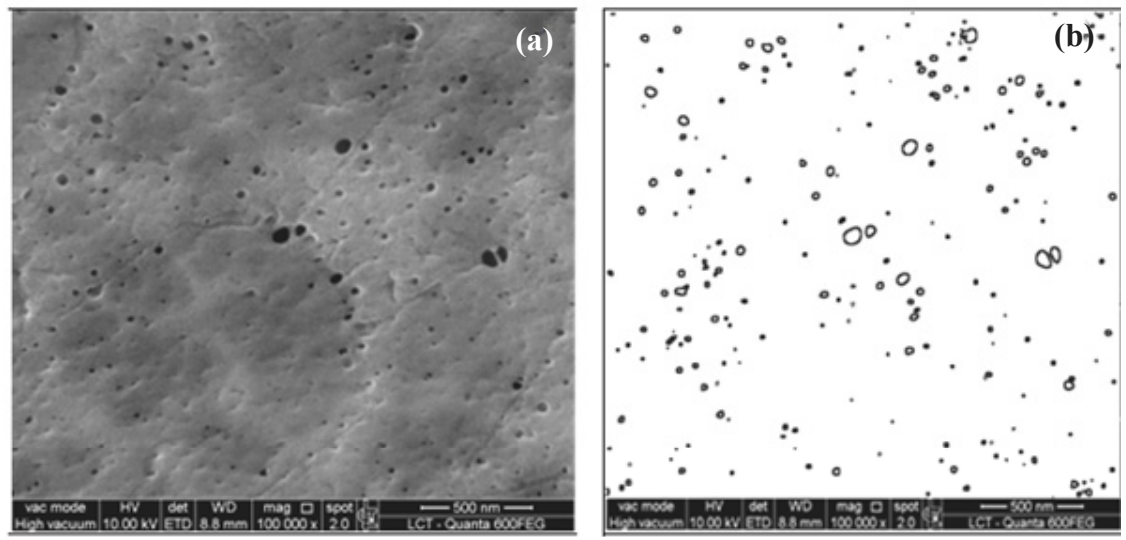

Figure 4: $(0 \% \mathrm{PVP}+4 \%$ clay $)$ membrane SEM surface image: (a) before manipulation; (b) after manipulation.

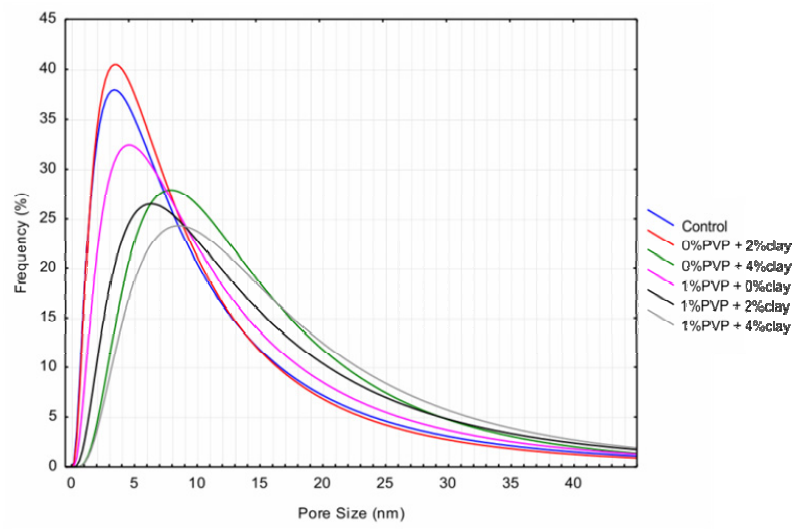

Figure 5: Membrane surface pore size distributions.

As observed in Figure 5, the ( $0 \%$ PVP $+4 \%$ clay) membrane, (1\% PVP $+0 \%$ clay) membrane, $(1 \%$ $\mathrm{PVP}+2 \%$ clay) membrane and ( $1 \% \mathrm{PVP}+4 \%$ clay) membrane had their distribution curve peaks shifted to larger pore diameters and showed a larger base distribution when compared to the control membrane and the ( $0 \%$ PVP $+2 \%$ clay) membrane. The most frequent pore diameters found were: control membrane - $3.5 \mathrm{~nm} ;(0 \%$ PVP $+2 \%$ clay $)$ membrane $-3.5 \mathrm{~nm}$; ( $0 \%$ PVP $+4 \%$ clay) membrane $-8 \mathrm{~nm} ;(1 \%$ PVP + $0 \%$ clay) membrane $-4.5 \mathrm{~nm}$; (1\% PVP $+2 \%$ clay $)$ membrane $-6.5 \mathrm{~nm}$; (1\% PVP $+4 \%$ clay) membrane - 9nm.

It was observed that, in most cases, except for the $(0 \%$ PVP $+2 \%$ clay $)$ membrane, the addition of clay nanoparticles and PVP increased the pore diameter as well as broaden the pore size distribution. These results can justify the improvement in the composite membrane permeability, except for the $(0 \%$ PVP $+2 \%$ clay) membrane, which presented a similar pore size distribution curve to the control membrane. This result indicates that the membrane internal morpho- logy can significantly affect membrane performance, as was observed by Mierzwa et al. (2012).

Table 7 presents the results for surface porosity. It can be noted that the addition of nanoclay changed surface porosity. Surface porosity increased with increasing nanoclay concentrations, but in most cases nanoclay addition failed to improve the surface porosity compared to the control membrane. The PVP and nanoclay combination presented the lowest surface porosity, probably because of the low PVP molecular weight.

Table 7: Membrane surface porosity.

\begin{tabular}{|l|c|c|}
\hline Membrane & $\begin{array}{c}\text { Total Pore Area } \\
\mathbf{( n m}^{\mathbf{2}} \mathbf{)}\end{array}$ & $\begin{array}{c}\text { Surface Porosity } \\
\mathbf{( \% )}\end{array}$ \\
\hline Control & 26.160 & 0.47 \\
0\% PVP + 2\% clay & 25.357 & 0.45 \\
0\% PVP + 4\% clay & 53.564 & 0.95 \\
1\% PVP + 0\% clay & 36.290 & 0.65 \\
1\% PVP + 2\% clay & 17.013 & 0.30 \\
1\% PVP + 4\% clay & 20.514 & 0.37 \\
\hline
\end{tabular}

Total membrane area: $5,606.068 \mathrm{~nm}^{2}$ 
Despite the highest surface porosity and permeate flux presented by the $(0 \% \mathrm{PVP}+4 \%$ clay) membrane, the surface porosity and surface pore size distribution results are not in such good agreement with the permeate test. This indicates that the internal pore morphology and structure have a major influence in the permeate flux performance.

\section{Membrane Internal Morphology Evaluation}

Membrane internal pore structure is an important morphology characteristic that can affect the membrane performance. The influence of additives on membrane internal morphology was evaluated by analysis of membrane cross-sectional SEM images. The cross-sectional SEM images for all cast membranes are presented in Figure 6 .

From Figure 6 it can be observed that the type and concentration of additive affected the membrane pore structure. Nanoclay cast membrane morphology is characterized by a superficial layer with macropore, a bottom layer which has a sponge-like pore structure with micro-pores and an intermediate layer, with finger-like pores and micro-pores. This kind of structure was expected since previous studies (Hwang et al., 2011) showed similar structures of composite PVDF-Nanoclay membranes.

On the other hand, membranes with PVP had a

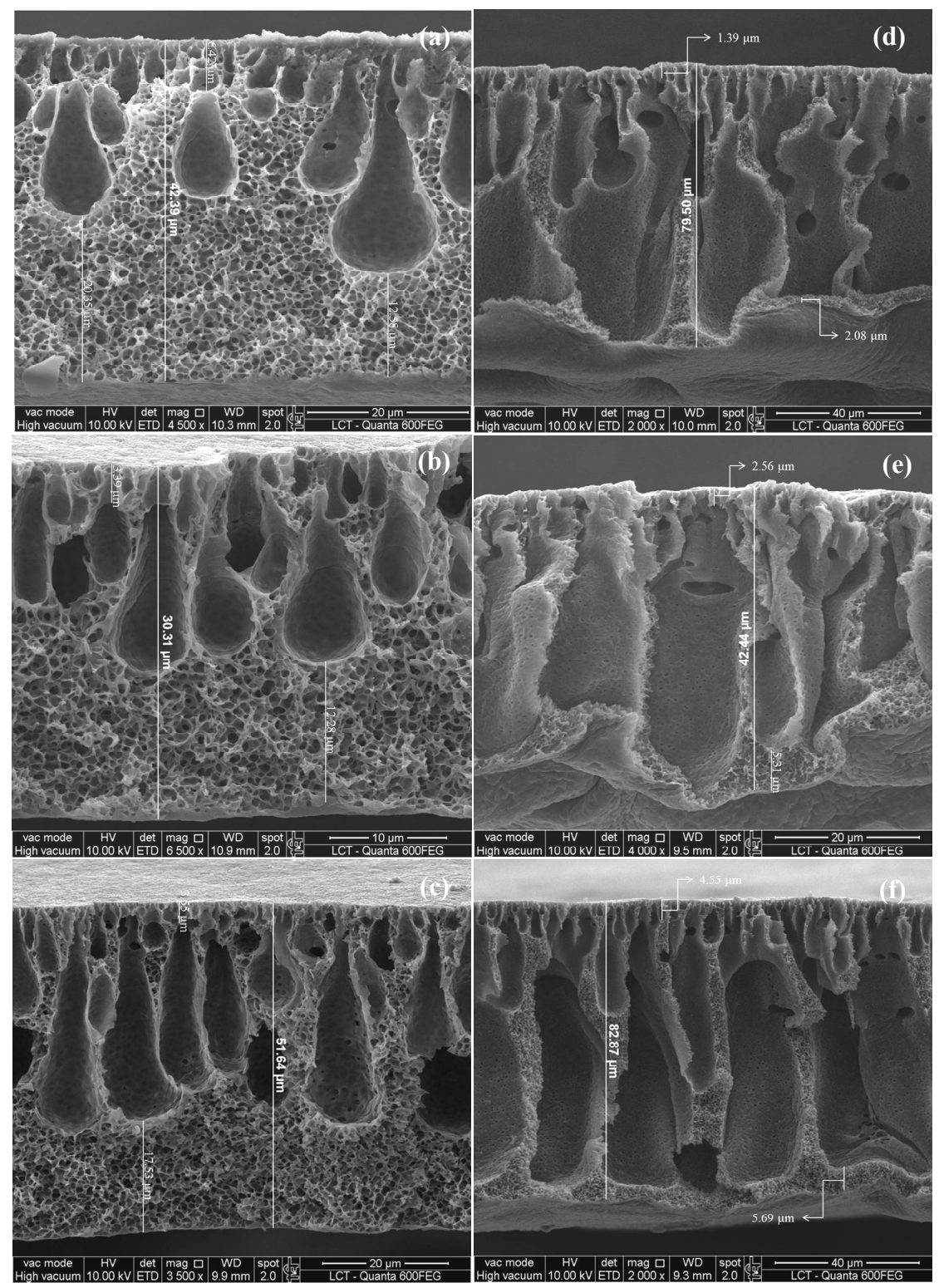

Figure 6: Membrane SEM cross-sectional images: (a) Control; (b) 0\% PVP $+2 \%$ clay; (c) $0 \%$ PVP $+4 \%$ clay; (d) $1 \%$ PVP $+0 \%$ clay; (e) $1 \%$ PVP + $2 \%$ clay; (f) $1 \%$ PVP $+4 \%$ clay. 
denser structure and also showed an intermediate layer characterized by macro-pores and longer and narrower finger-like pore structures. However, it shows an increasing number of finger-like pores. Besides, it can be observed that PVP introduction decreases the average pore size. These changes are proportional to the added PVP concentration added.

Membranes thickness characteristics are shown in Table 8.

It was expected that the final membrane had a $20 \%$ reduction in thickness. However, it can be observed in Table 8, the thickness reduction varies from $17 \%$ to $70 \%$; the thicker membrane (1\% PVP $+4 \%$ clay) had an estimated thickness of $82.87 \mu \mathrm{m}$ and the thinner membrane ( $0 \%$ PVP $+2 \%$ clay) $30.31 \mu \mathrm{m}$. Membranes with only nanoclay ( $0 \%$ PVP $+2 \%$ clay membrane and $0 \%$ PVP $+4 \%$ clay membrane) showed the highest reduction in thickness compared to the membranes with nanoclay and PVP additions $(1 \% \mathrm{PVP}+2 \%$ clay membrane and $1 \% \mathrm{PVP}+4 \%$ clay membrane).

Table 8: Membrane thickness characteristics.

\begin{tabular}{|l|c|c|c|c|}
\hline \multirow{2}{*}{ Membrane } & \multicolumn{3}{|c|}{ Thickness $(\boldsymbol{\mu m})$} & \% reduction \\
\cline { 2 - 5 } & Total & $\begin{array}{c}\text { Surface } \\
\text { Layer }\end{array}$ & $\begin{array}{c}\text { Bottom } \\
\text { Layer }\end{array}$ & $\begin{array}{c}\text { in thickness } \\
\text { in }\end{array}$ \\
\hline Control & 42.39 & 6.42 & 20.35 & 57.61 \\
0\% PVP + 2\% clay & 30.31 & 3.39 & 12.28 & 69.69 \\
0\% PVP + 4\% clay & 51.64 & 3.55 & 17.53 & 48.36 \\
1\% PVP + 0\% clay & 79.50 & 1.39 & 2.08 & 20.50 \\
1\% PVP + 2\% clay & 42.44 & 2.56 & 5.31 & 57.56 \\
$1 \%$ PVP + 4\% clay & 82.87 & 4.55 & 5.69 & 17.13 \\
\hline
\end{tabular}

${ }^{1}$ Casting knife $100 \mu \mathrm{m}$

Furthermore, the additives had different effects on the membrane internal layer thickness. The addition of nanoclay decreased the surface and bottom layer thicknesses, increased the intermediate layer thickness and also the number of finger-like pores. These changes are proportional to nanoclay concentration. The PVP and PVP-Nanoclay membranes had a reduction in bottom layer thickness compared to the nanoclay membranes.

Comparing the differences in internal membranes pore morphology and membranes performance, it can be noted that increasing the finger-like pore profile in the intermediated membrane layer improved permeability. Moreover, a less dense structure with a superficial layer with macro-pores, an intermediate layer with a finger-like pore structure and micro-pores and a bottom layer with sponge-like pore structure and micro-pores provides an improvement in membrane permeability.

\section{CONCLUSIONS}

In this study, the influence of clay nanoparticles and PVP on the performance of PVDF membranes was evaluated.

The results of the performance evaluation tests suggest that the addition of clay nanoparticles and pore former (PVP) can improve the pure water permeate flux compared with a neat PVDF membrane. Moreover, the additions of only clay nanoparticles as an additive presented the best results for pure water permeate flux among all PVDF membranes compared. The use of $4 \% \mathrm{wt}$ nanoclay concentration in the solution resulted in the membrane with the highest ultrapure water permeability.

The contact angle results indicate that additives increased the contact angle and decreased hydrophilicity, but, at the same time, the additives improved membrane permeability for pure water. This demonstrated that hydrophilicity is not responsible for the performance improvement.

Although the additives increased the distributions of pore diameter and the frequency of pores with higher diameter, composite membranes did not show better surface porosity results compared with the control membrane.

Furthermore, it was verified that the membrane surface porosity increased with increasing clay nanoparticle concentration. It was also observed that the morphology of this kind of membrane is characterized by a thin surface layer, with macro-pores, a thin bottom layer, which has a sponge structure with micro-pores and a thick intermediate layer, with finger-like pores and macro-pores. It was also verified that the addition of PVP promotes a denser morphology compared to membranes without it. The effect of clay nanoparticle addition on membrane performance seems to be associated with the changes in membrane morphology, increasing surface porosity and the extent of finger-like pores.

\section{ACKNOWLEDGEMENTS}

The authors want to express their gratitude to the Financiadora de Estudos e Projetos (FINEP), for the financial support, Arkema Química Ltda, for the PVDF donation and Liz Zanchetta D'Agostino of 
Laboratório de Caracterização Tecnológica (LCT), for the SEM analysis.

\section{NOMENCLATURE}

$\begin{array}{ll}\text { A } & \begin{array}{l}\text { Membrane effective surface } \\ \text { area }\end{array} \\ \mathrm{J} & \text { Permeate flux } \\ \mathrm{R}_{\mathrm{M}} & \text { Hydraulic resistance } \\ \mathrm{t} & \text { Permeation time } \\ \mathrm{V} & \text { Permeate volume } \\ \Delta \mathrm{P} & \text { Transmembrane pressure }\end{array}$

$\mathrm{m}^{2}$
$\mathrm{~m}^{3} / \mathrm{m}^{2} . \mathrm{s}$
$\mathrm{m}^{-1}$
$\mathrm{~s}$
$\mathrm{~m}^{3}$
$\mathrm{~Pa}$

\section{Greek Letters}

$\theta \quad$ Contact angle

$\mu \quad$ Dynamic water viscosity

Pa.s

\section{REFERENCES}

AMSTJ, A. O., Certified Membrane Modules for Water Supply Catalogue Book 2001. AMSTJ, Tokyo (2001).

Anadão, P., Sato, L. F., Wiebeck, H. and ValenzuelaDíaz, F. R., Montmorillonite as a component of polysulfone nanocomposite membranes. Applied Clay Science, 48(1-2), p. 127-132 (2010).

Anadão, P., Wiebeck, H. and Valenzuela-Díaz, F. R., Panorama da Pesquisa Acadêmica Brasileira em Nanocompósitos. Polímeros, 21(5), p. 443-452 (2011). (In Portuguese).

Aptel, P. and Buckley, C. A., Categories of membrane Operations, In: Water Treatment Membrane Processes. First Ed. McGraw-Hill. USA, p. 2.1-2.24 (1996).

ArkemaInc, KYNAR ${ }^{\circledR}$ and KYNAR FLEX® PVDF (2009).

Arnal, J., García-Fayos, B., Sancho, M., Verdú, G. and Lora, J., Design and installation of a decentralized drinking water system based on ultrafiltration in Mozambique. Desalination, 250(2), p. 613-617 (2010).

Arnal, J., Sancho, M., Verdú, G., Lora, J., Marin, J. and Chiller, J., Selection of the most suitable ultrafiltration membrane for water disinfection in developing countries. Desalination, 168, p. 265-270 (2004).

AstmInternational, ASTM D882 - 12 - Standard Test Method for Tensile Properties of Thin Plastic Sheeting. (2012).

Baker, R., Membrane Thechnology and Applications. J. Willey and Sons, New York (2004).
BasfCorporation, Technical Data Sheet: N-Methyl-2pyrrolidone Ultra Pure Grade (1999).

BccResearch, BCC Research Report NAN051A, In: http://www.bccresearch.com/report/nanotechnolo gy-water-treatment-nan051a.html?tab=highlightand highlightKeyword=membrane (2011a). (Accessed: November 2, 2012).

BccResearch, BCC Research Report MST036C, In: http://www.bccresearch.com/report/advanced-techmunicipal-water-treatment-mst036c.html?tab=high lightandhighlightKeyword=membrane. (2011b). (Accessed: November 2, 2012).

Bhattacharya, A. and Misra, B., Grafting: A versatile means to modify polymers: Techniques, factors and applications. Progress in Polymer Science, 29(8), p. 767-814 (2004).

Bottino, A., Camera-Roda, G., Capannelli, G. and Munari, S., The formation of microporous polyvinylidene difluoride membranes by phase separation. Journal of Membrane Science, 57(1), p. 1-20 (1991).

Bottino, A., Capannelli, G. and Comite, A., Novel porous poly(vinylidene fluoride) membranes for membrane distillation. Desalination, 183(1-3), p. 375-382 (2005).

Bottino, A., Capannelli, G. and Comite, A., Preparation and characterization of novel porous PVDF$\mathrm{ZrO}_{2}$ composite membranes. Desalination, 146(13), p. 35-40 (2002).

Bottino, A., Capannelli, G., D'asti, V. and Piaggio, P., Preparation and properties of novel organicinorganic porous membranes. Separation and $\mathrm{Pu}-$ rification Technology, 22-23, p. 269-275 (2001).

Bottino, A., Capannelli, G., Munari, S. and Turturro, A., Solubility parameters of poly(vinylidene fluoride). Journal of Polymer Science Part B: Polymer Physics, 26(4), p. 785-794 (1988).

Brant, J. A. and Childress, A. E., Colloidal adhesion to hydrophilic membrane surfaces. Journal of Membrane Science, 241(2), p. 235-248 (2004).

Cao, X., Ma, J., Shi, X. and Ren, Z., Effect of $\mathrm{TiO}_{2}$ nanoparticle size on the performance of PVDF membrane. Applied Surface Science, 253(4), p. 2003-2010 (2006).

Chae, S.-R., Yamamura, H., Ikeda, K. and Watanabe, Y., Comparison of fouling characteristics of two different poly-vinylidene fluoride microfiltration membranes in a pilot-scale drinking water treatment system using pre-coagulation/sedimentation, sand filtration and chlorination. Water Research, 42(8-9), p. 2029-2042 (2008).

Chan, R. and Chen, V., Characterization of protein fouling on membranes: Opportunities and challenges. Journal of Membrane Science, 242(1-2), 
p. 169-188 (2004).

Chang, S., Waite, T. and Fane, A., A simplified model for trace organics removal by continuous flow PAC adsorption/submerged membrane processes. Journal of Membrane Science, 253(1-2), p. 81-87 (2005).

Cheng, L.-P., Effect of temperature on the formation of microporous PVDF membranes by precipitation from 1-octanol/DMF/PVDF and water/DMF/ PVDF systems. Macromolecules, 32(20), p. 66686674 (1999).

Cheryan, M., Ultrafiltraton and Microfiltration Handbook. Second Ed. CRC Press, USA (1998).

Cho, J., Amy, G. and Pellegrino, J., Membrane filtration of natural organic matter: Factors and mechanisms affecting rejection and flux decline with charged ultrafiltration (UF) membrane. Journal of Membrane Science, 164(1-2), p. 89-110 (2000).

Cui, Z.-Y., Du, C.-H., Xu, Y.-Y., Ji, G.-L. and Zhu, B.-K., Preparation of porous PVDF membrane via thermally induced phase separation using sulfolane. Journal of Applied Polymer Science, 108(1), p. 272-280 (2008).

Dargaville, T. R., George, G. A., Hill, D. J. and Whittaker, A. K., High energy radiation grafting of fluoropolymers. Progress in Polymer Science, 28(9), p. 1355-1376 (2003).

Dickey, C. and Mcdaneil, J., Patente $\mathrm{N}^{\circ}$ U.S. Pat. 3.896.196 (1975).

DNPM, D. N., Sumário Mineral 2011 do Departamento Nacional de Produção Mineral DNPM, In:https://sistemas.dnpm.gov.br/publicacao/mostr a_imagem.asp?IDBancoArquivoArquivo $=6358$. (2011). (In Portuguese).

Du, J. R., Peldszus, S., Huck, P. M. and Feng, X., Modification of poly(vinylidene fluoride) ultrafiltration membranes with poly(vinyl alcohol) for fouling control in drinking water treatment. Water Research, 43(18), p. 4559-4568 (2009).

Ebert, K., Fritsch, D., Koll, J. and Tjahjawiguna, C., Influence of inorganic fillers on the compaction behaviour of porous polymer based membranes. Journal of Membrane Science, 233(1-2), p. 71-78 (2004).

EPA, U. S., Membrane Filtration Guidance Manual. Office of Water Vols. EPA 815-D-03-008 (Proposal Draft). EPA. USA (2003).

Fiksdal, L. and Leiknes, T., The effect of coagulation with $\mathrm{MF} / \mathrm{UF}$ membrane filtration for the removal of virus in drinking water. Journal of Membrane Science, 279(1-2), p. 364-371 (2006).

FreedoniaGroupInc., Market Research - Knowledge, Identified and Delivered, In: http://www.market
research.com/Freedonia-Group-Inc-1247/Membrane -Separation-Technologies-7036907/(2011). (Accessed: March 28, 2012).

Fusp, F. d., Plano da Bacia Hidrográfica do Alto Tietê. Comitê da Bacia Hidrográfica do Alto Tietê. São Paulo (2009). (In Portuguese).

Gao, W., Liang, H., Ma, J., Han, M., Chen, Z., Han, Z. and Li, G., Membrane fouling control in ultrafiltration technology for drinking water production: A review. Desalination, 272(1-3), p. 1-8 (2011).

Georlette, P. and Leva, J., Patente $\mathrm{N}^{\mathrm{o}}$ U.S. Pat. 4.425.443 (1984).

Ghaemi, N., Madaeni, S. S., Alizadeh, A., Rajabi, H. and Daraei, P., Preparation, characterization and performance of polyethersulfone/organically modified montmorillonite nanocomposite membranes in removal of pesticides. Journal of Membrane Science, 382(1-2), p. 135-147 (2011).

Ghosh, R., Study of membrane fouling by BSA using pulsed injection technique. Journal of Membrane Science, 195(1), p. 115-123 (2002).

Grasselli, M. and Betz, N., Making porous membranes by chemical etching of heavy-ion tracks in b-PVDF films. Nuclear Instruments and Methods in Physics Research Section B: Beam Interactions with Materials and Atoms, 236(1-4), p. 501-507 (2005).

Gu, M., Zhang, J., Wang, X., Tao, H. and Ge, L., Formation of poly(vinylidene fluoride) (PVDF) membranes via thermally induced phase separation. Desalination, 192(1-3), p. 160-167 (2006).

Guo, X., Zhang, Z., Fanga, L. and Sua, L., Study on ultrafiltration for surface water by a polyvinylchloride hollow fiber membrane. Desalination, 238(1-3), p. 183-191 (2009).

Habert, A., Borges, C. and Nobrega, R., Processos de Separação. E-papers Serviços Editoriais Ltda. Rio de Janeiro (2006). (In Portuguese).

Hallé, C., Huck, P. M., Peldszus, S., Haberkamp, J. and Jekel, M., Assessing the performance of biological filtration as pretreatment to low pressure membranes for drinking water. Enviromental Science and Technology, 43(10), p. 3878-3884 (2009).

Halpern, D. F., Mcardle, J. and Antrim, B., UF Pretreatment for SWRO: Pilot Studies. Desalination, 182(1-3), p. 323-332 (2005).

Hashim, N. A., Liu, F. and Li, K., A simplified method for preparation of hydrophilic PVDF membranes from an amphiphilic graft copolymer. Journal of Membrane Science, 345(1-2), p. 134141 (2009).

Hashim, N. A., Liu, F. and Li, K., Stability of PVDF hollow fibre membranes in sodium hydroxide 
aqueous solution. Chemical Engineering Science, 66(8), p. 1565-1575 (2011).

Hong, H., Kim, H., Lee, Y. and Yang, J., Removal of anionic contaminants by surfactant modified powdered activated carbon (SM-PAC) combined with ultrafiltration. Journal of Hazardous Materials, 170(2-3), p. 1242-1246 (2009).

Howe, K. J. and Clark, M. M., Fouling of microfiltration and ultrafiltration membranes by natural waters. Environmental Science and Technology, 36(16), p. 3571-3576 (2002).

Huang, H., Schwab, K. and Jacangelo, J. G., Pretreatment for low pressure membranes in water treatment: a review. Enviromental Science and Technology, 43(9), p. 3011-3019 (2009).

Hwang, H., Kim, D., Kim, H., Hong, Y. and Nam, S., Effect of nanoclay on properties of porous PVdF membranes. Transactions of Nonferrous Metals Society of China, 21, p. 141-147 (2011).

InternationalStandard., Plastics - Film and sheeting Measurement of water contact angle of coronatreated films. ISO 15989, p. 1-12 (2004).

Junga, B. J., Yoona, J. K., Kima, B. and Rheeb, H., Effect of crystallization and annealing on polyacrylonitrile membranes for ultrafiltration. Journal of Membrane Science, 246(1), p. 67-76 (2005).

Kato, K., Uchida, E., Kang, E., Uyama, Y. and Ikada, Y., Polymer surface with graft chains. Progress in Polymer Science, 28(2), 209-259 (2003).

Katsoufidou, K., Yiantsios, S. and Karabelas, A., An experimental study of UF membrane fouling by humic acid and sodium alginate solutions: the effect of backwashing on flux recovery. Desalination, 220(1-3), p. 214-227 (2008).

Kennedy, M. D., Kamanyi, J., Rodríguez, S. G., Lee, N. H., Schippers, J. C. and Amy, G., Water Treatment by Microfiltration and Ultrafiltration, In: Advanced Membrane Technology and Applications, p. 131-170. Wiley. USA (2008).

Khulbe, K., Feng, C., Matsuura, T., Kapantaidakis, G., Wessling, M. and Koops, G., Characterization of polyethersulfone-polyimide hollow fiber membranes by atomic force microscopy and contact angle goniometery. Journal of Membrane Science, 226(1-2), p. 63-73 (2003).

Kim, J. Y., Kim, Y. D., Kanamori, T., Lee, H. K. and Baik, K., Vitrification phenomena in polysulfone/ $\mathrm{NMP} /$ water system. Journal of Applied Polymer Science, 71(2), p. 431-438 (1999).

Kim, J., Davies, S. H., Baumann, M. J., Tarabara, V. V. and Masten, S. J., Effect of ozone dosage and hydrodynamic conditions on the permeate flux in a hybrid ozonation-ceramic ultrafiltration system treating natural waters. Journal of Membrane
Science, 311(1-2), p. 165-172 (2008).

Kim, S. S. and Loyd, D. R., Thermodynamics of polymer/diluent systems for thermally induced phase separation: 3. Liquid-liquid phase separation systems. Polymer, 33(5), p. 1047-1057 (1992).

Kimura, K., Hane, Y., Watanabe, Y., Amy G. and Ohkuma, N., Irreversible membrane fouling during ultrafiltration of surface water. Water Research, 38(14-15), p. 3431-3441 (2004).

Kubota, N., Hashmoto, T. and Mori, Y., Microfiltration and Ultrafiltration. In: Advanced Membrane Technology and Applications, p. 101-129, John Wiley \& Sons, Inc. USA (2008).

Kou, R., Xu, Z., Deng, H., Liu, Z., Seta, P. and Xu, Y., Surface modification of microporus polypropylene membranes by plasma-induce graft polymerization of $\alpha$-allyl glucoside. Langmuir, 19(17), p. 6869-6875 (2003).

Labsinth, Ficha de Informação de Segurança do Álcool Isopropilico (2010). (In Portuguese).

Labsinth, Ficha de Informação de Segurança do 1metil-2-pirrolodona (2012a). (In Portuguese).

Labsinth, Ficha de Informação de Segurança do Metabissulfito de Sódio (2012b). (In Portuguese).

Laîné, J., Vial, D. and Moula, P., Status after 10 years of operation - overview of UF technology today. Desalination, 131(1-3), p. 17-25 (2000).

Lee, E. K., Chen, V. and Fane, A., Natural organic matter (NOM) fouling in low pressure membrane filtration - effect of membranes and operation modes. Desalination, 218(1-3), p. 257-270 (2008).

Li, K., Membrane Science and Membrane Separation Processes. Department of Chemical Engineering and Chemical Technology - Imperail College, London (2008).

Lin, D., Chang, C., Huang, F. and Cheng, L., Effect of salt $\mathrm{a}$ on the formation of microporous poly(vinylidene fluoride) membranes by phase inversion from $\mathrm{LiClO} 4 /$ water/DMF/PVDF system. Polymer, 44(2), p. 413-422 (2003).

Lipp, P., Baldauf, G., Schmitt, A. and Theis, B., Long-term behaviour of UF membranes treating surface water. Water Science and Technology: Water Supply, 3(5), p. 31-37 (2003).

Liu, F., Abed, M. M. and Li, K., Preparation and characterization of poly(vinylidene fluoride) (PVDF) based ultrafiltration membranes using nano gama- $\mathrm{Al}_{2} \mathrm{O}_{3}$. Journal of Membrane Science, 366(1-2), p. 97-103 (2011a).

Liu, F., Du, C., Zhu, B. and Xu, Y., Surface immobilization of polymer brushes onto porous poly(vinylidenefluoride) membrane by electron beam to improve the hydrophilicity and fouling resistance. Polymer, 48(10), 2910-2918 (2007). 
Liu, F., Hashim, N. A., Liu, Y., Abed, M. M. and Li, K., Progress in the production and modification of PVDF membranes. Journal of Membrane Science, 375(1-2), p. 1-27 (2011b).

Liu, F., Xu, Y., Zhu, B., Zhang, F. and Zhu, L., Preparation of hydrophilic and fouling resistant poly(vinylidene fluoride) hollow fiber membranes. Journal of Membrane Science, 345(1-2), p. 331-339 (2009).

Liu, F., Zhu, B. and Xu, Y., Improving the hydrophilicity of poly(vinylidene fluoride) porous membranes by electron beam initiated surface grafting of AA/SSS binary monomers. Applied Surface Science, 253(4), p. 2096-2101 (2006).

Lovinger, A. J. and Reed, D. J., Inhomogeneous thermal degradation of poly(vinylidenefluoride) crystallized from the melt. Macromolecules, 13(4), p. 989-994 (1980).

Ma, Y., Shi, F., Wang, Z., Wu, M., Ma, J. and Gao, C., Preparation and characterization of PSf/clay nanocomposite membranes with PEG 400 as a pore forming additive. Desalination, 286, p. 131137 (2012).

Mallevialle, J., Odendaal, P. E. and Wiesner, M. R., The Emergence of Membranes in Water and Wastewater Treatment. In: Water Treatment Membrane Processes. First Ed. McGraw-Hill, USA, p. 2.1-2.24 (1996).

Martinez-Sosa, D., Helmreich, B., Netter, T., Paris, S., Bischof, F. and Horn, H., Anaerobic submerged membrane bioreactor (AnSMBR) for municipal wastewater treatment under mesophilic and psychrophilic temperature conditions. Bioresource Technology, 102(22), p. 10377-10385 (2011).

Maximous, N., Kakhla, G., Wan, W. and Wong, K., Preparation, characterization and performance of $\mathrm{Al}_{2} \mathrm{O}_{3} / \mathrm{PES}$ membrane for wastewater filtration. Journal of Membrane Science, 341(1-2), p. 67-75 (2009).

Mierzwa, J. C., Arieta, V., Verlage, M., Carvalho, J. and Vecitis, C. D., Effect of clay nanoparticles on the structure and performance of polyethersulfone. Desalination, 314, p. 147-158 (2013).

Mierzwa, J. C., Silva, M. C. C., Veras, L. R. V., Subtil, E. L., Rodrigues, R., Li, T. and Landenberger, K. R., Enhancing sipiral-wound ultrafiltration performance for direct drinking water treatment through operational procedures improvement: A feasible option for the Sao Paulo Metropolitan Region. Desalination, 307, p. 68-75 (2012a).

Mierzwa, J. C., Vecitis, C. D., Carvalho, J., Arieta, V. and Verlage, M., Anion dopant effects on the structure and performance of polyethersulfone membranes. Journal of Membrane Science, 421422, p. 91-102 (2012b).

Mijovic, J., Luo, H. and Han, C. D., Propertymorphology relationships of polymethylmethacrylate/polyvinylidenefluoride blends. Polymer Engineering and Science, 22(4), p. 234-240 (1982).

Monticelli, O., Bottino, A., Scandale, I., Capannelli, G. and Russo, S., Preparation and properties of polysulfone-clay composite membranes. Journal of Applied Polymer Science, 103(6), p. 36373644 (2007).

Mosqueda-Jimenez, D. B., Huck, P. M. and Basu, O. D., Fouling characteristics of an ultrafiltration membrane used in drinking water treatment. Desalination, 230(1-3), p. 79-91 (2008).

Mozia, S. and Tomaszewska, M., Treatment of surface water using hybrid processes - adsorption on PAC and ultrafiltration. Desalination, 162, p. 23-31 (2004).

Mozia, S. and Tomaszewska, M. and Morawski, A. W., Application of an ozonation-adsorptionultrafiltration system for surface water treatment. Desalination, 190(1-3), p. 308-314 (2006).

Mulder, M., Basic Principles of Membrane Technology, second Ed. Kluwer Academic Publishers. Dordrecht (2003).

Munari, S., Bottino, A. and Capannelli, G., Casting and performance of polyvinylidene fluoride based membranes. Journal of Membrane Science, 16, p. 181-193 (1983).

Nogueira, F. T., Síntese e caracterização de membranas de filme fino composto de polissulfona/ quitosana reticulada com glutaraldeído. Ph.D. Thesis, Escola Politécnica da Universidade de São Paulo - Departamento de Engenharia Hidráulica e Ambiental (2012). (In Portuguese).

Porter, M. C., Ultrafiltration. In: Handbook of Industrial Membrane Technology. Noyes Publications (1990).

Prici, S., Posocco, P., Scocchi, G. and Fermeglia, M., Polymer-Clay Nanocomposites. In: Handbook of Nanophysics: Functional Nanomaterials. CRC Press, p. $3.1-3.14$ (2010).

Pucca, P. T., Produção e caracterização de membranas de microfiltração pelo método de inversão de fases, utilizando polisulfona como matéria prima. Master Thesis, Escola Politécnica da Universidade de São Paulo - Departamento de Engenharia Hidráulica e Sanitária (2010). (In Portuguese).

Schneider, R. P. and Tsutiya, M. T., Membranas Filtrantes para o Tratamento de Água, Esgoto e Água de Reúso $1^{\mathrm{a}}$ Ed. Associação Brasileira de Engenharia Sanitária e Ambiental. São Paulo (2001). (In Portuguese). 
Sigma-Aldrich., Ficha de Informação de Segurança de Produtos Químicos: Argila, Nanômetro PGV (Bentonita Hidrofílica) (2011). (In Portuguese).

Sigma-Aldrich., Ficha de Informação de Segurança de Produtos Químicos: Polivinilpirrolidona peso molecular médio 10.000 (2011). (In Portuguese).

Stengaard, F., Preparation of asymmetric microfiltration membranes and modification of their properties by chemical treatment. Journal of Membrane, 36, p. 257-275 (1988).

$\mathrm{Su}$, Y., Chen, C., Li, Y. and Li, J., PVDF membrane formation via thermally induced phase separation. Journal of Macromolecular Science, Part A: Pure and Applied Chemistry, 44(1), p. 99-104 (2007).

Sukitpaneenit, P. and Chung, T., Molecular elucidation of morphology and mechanical properties of PVDF hollow fiber membranes from aspects of phase inversion, crystallization and rheology. Journal of Membrane Science, 340(1-2), p. 192205 (2009).

Till, S. and Mallia, H., Membrane Bioreactors: Wastewater Treatment Applications to Achieve High Quality Effluent - 64th Annual Water Industry Engineers and Operators' Conference Water Industry Group. Fisher Stewart. Bendigo, p. 58-65 (2001).

Wang, P., Wang, Z., Wu, Z. and Mai, S., Fouling behaviours of two membranes in a submerged membrane bioreactor for municipal wastewater treatment. Journal of Membrane Science, 382(12), p. 60-69 (2011).

Wang, X., Zhang, L., Sun, D., An, Q. and Chen, H., Formation mechanism and crystallization of poly(vinylidene fluoride) membrane via immersion precipitation method. Desalination, 236, p. 170-178 (2009).

Wang, Z., Wu, Z., Yu, G., Liu, J. and Zhou, Z., Relationship between sludge characteristics and membrane flux determination in submerged membrane bioreactors. Journal of Membrane Science, 284(1-2), p. 87-94 (2006).
Weber, P. and Knauf, R., Ultrafiltration of surface water with MIOLPURE FW50 hollow fibre module. Desalination, 119(1-3), p. 335-339 (1998).

Witte, P. V., Dijkstra, P. J., Berg, J. W. and Feijien, J., Phase separation processe in polymer solutions in relation to membrane formation - Review. Journal of Membrane Science, 117(1-2), p. 1-31 (1996).

Xia, S., Liu, Y., Li, X. and Yao, J., Drinking water production by ultrafiltration of Songhuajiang River with PAC adsorption. Journal of Environmental Sciences, 19(5), p. 536-539 (2007).

Xiangli, Q., Zhenjia, Z., Nongcun, W., Wee, V., Low, M., Loh, C. S. and Hing, N., Coagulation pretreatment for a large-scale ultrafiltration process treating water from the Taihu River. Desalination, 230(1-3), p. 305-313 (2008).

Yamamura, H., Kimura, K. and Watanabe, Y., Mechanism involve in the evolution of physically irreversible fouling in microfiltration and ultrafiltration membranes used for drinking water treatment. Environmental Science Technology, 41(19), p. 6789-6794 (2007).

Yan, L., Li, Y. S., Xiang, C. B. and Xianda, S., Effect of nano-sized $\mathrm{Al}_{2} \mathrm{O}_{3}$-particle addition on PVDF ultrafiltration membrane performance. Journal of Membrane Science, 276(1-2), p. 162-167 (2006).

Zhao, Y., Qian, Y., Zhu, B. and Xu, Y., Modification of porous poly(vinylidene fluoride) membrane using amphiphilic polymers with different structures in phase inversion process. Journal of Membrane Science, 310(1-2), p. 567-576 (2008).

Zularisam, A., Ismail, A., Salim, M., Sakinah, M. and Ozaki, H., The effects of natural organic matter (NOM) fractions on fouling characteristics and flux recovery of ultrafiltration membranes. Desalination, 212(1-3), p. 191-208 (2007).

Zurarisam, A. W., Ismail, A. F. and Salin, R., Behaviours of natural organic matter in membrane filtration for surface water treatment - a review. Desalination, 194(1-3), p. 211-231 (2006). 